\title{
Small low-temperature district heating network development prospects
}

Volkova, Anna; Krupenski, Igor; Pieper, Henrik; Ledvanov, Aleksandr; Latõšov, Eduard; Siirde, Andres

Published in:

Energy

Link to article, DOI:

10.1016/j.energy.2019.04.083

Publication date:

2019

Document Version

Peer reviewed version

Link back to DTU Orbit

Citation (APA):

Volkova, A., Krupenski, I., Pieper, H., Ledvanov, A., Latõšov, E., \& Siirde, A. (2019). Small low-temperature district heating network development prospects. Energy, 178, 714-722.

https://doi.org/10.1016/j.energy.2019.04.083

\section{General rights}

Copyright and moral rights for the publications made accessible in the public portal are retained by the authors and/or other copyright owners and it is a condition of accessing publications that users recognise and abide by the legal requirements associated with these rights.

- Users may download and print one copy of any publication from the public portal for the purpose of private study or research.

- You may not further distribute the material or use it for any profit-making activity or commercial gain

- You may freely distribute the URL identifying the publication in the public portal

If you believe that this document breaches copyright please contact us providing details, and we will remove access to the work immediately and investigate your claim 


\title{
Small low-temperature district heating network development prospects
}

\author{
Anna Volkova a*, Igor Krupenskiab, Henrik Pieperc ${ }^{\mathrm{c}}$, Aleksandr Ledvanov ${ }^{\mathrm{b}}$, Eduard Latõšova \\ Andres Siirde ${ }^{a}$ \\ a Tallinn University of Technology, Department of Energy Technology, \\ Ehitajate tee 5, Tallinn, 19086, Estonia \\ b HeatConsult OÜ, Valukoja 8, Tallinn, 11415, Estonia \\ c Technical University of Denmark, Department of Mechanical Engineering, Nils Koppels Allé \\ Building 403, 2800, Kgs. Lyngby, Denmark
}

Keywords: Low-temperature district heating, small district heating networks, $4^{\text {th }}$ generation district heating, seawater heat pumps

\begin{abstract}
One main obstacle to the implementation of low-temperature district heating is the existing infrastructure along with consumer heating devices that were usually designed for higher operating temperatures. If a DHN is installed for a new urban area, these obstacles can be avoided. This study presents an analysis of alternative heat supply scenarios for the newly developing city subdistrict of Kopli (Tallinn, Estonia). The following scenarios were analysed from economic and environmental aspects: scenario A-connection to the existing DHN (supply/return temperatures $95^{\circ} \mathrm{C} / 55^{\circ} \mathrm{C}$, gasfired boiler house); scenario B-small local $\mathrm{DHN}\left(80^{\circ} \mathrm{C} / 40^{\circ} \mathrm{C}\right.$, small gas-fired boiler house); scenario C-small local LTDHN $\left(60^{\circ} \mathrm{C} / 35^{\circ} \mathrm{C}\right.$, small gas-fired boiler house, integrated large-scale heat pump using seawater as heat source). The results of the study have shown that the primary energy consumption per $1 \mathrm{MWh}$ of heat consumed is $1.33 \mathrm{MWh}$ for scenario $\mathrm{A}, 1.15 \mathrm{MWh}$ for scenario $\mathrm{B}$, and $0.71 \mathrm{MWh}$ for scenario $\mathrm{C}$. To achieve IRR $=7 \%$, a 4 year discounted payback period was calculated for scenario B, with the NPV of 1.000 .000 EUR after the period of 10 years. For scenario $C$, the payback period is more than 5 years, and the NPV is 2.600 .000 EUR after 10 years.
\end{abstract}

\section{Introduction}

Many conditions must be satisfied by the district heating (DH) system as a heat supply technology for it to be considered an energy-efficient and environmentally friendly solution. One of the most significant factors for the development of future sustainable DH systems is the possibility to use lowtemperature heat carrier [1]. Low-temperature district heating networks (DHN) have many advantages, including low heat loss and ability to utilise renewable and waste heat energy sources. Many studies have investigated reducing heat losses of DHNs by converting them to LTDHN. Network heat loss is a very important factor, associated with the supply and return temperatures of the system's heating carrier [2]. Dalla Rosa [3] proposed a methodology for calculating steady state heat loss for different pipe types and configurations with a particular focus on low-temperature appliances. Li and Svendsen [4] stated that the absolute network heat loss would be much lower for LTDHNs, although the relative DHN heat loss would not change significantly. Köfinger et al. [5] showed that in areas with high energy demand the effect of lowering temperature would not be significant, but for areas with lower heat demand densities heat loss would be considerably reduced. Other studies investigated the transition of existing DHN towards LTDHN. Räma and Sipilä [6] showed that low heat loss is associated with either a reduction of transport capacity of the pipes within the network or with a significant pressure drop. Nord et al. [7] have analysed the challenges in the transition to LTDH and estimated the increased competitiveness in low heat density areas. Volkova et al. [8] have determined that temperature reduction is limited by consumer heating appliances. One of the main barriers to lower supply and return temperatures are high radiator design temperatures in existing buildings $[9,10]$. These obstacles can be avoided if a DHN is installed in a new urban area by constructing energy-efficient low-energy buildings with floor heating and heat recovery ventilation.

Another major advantage of low supply temperature is the use of low-temperature renewable heat sources and waste heat, such as solar thermal energy, geothermal heating, seawater and industrial waste heat. Soloha et al. [11] explored the possibilities of implementing a large-scale solar collector field into the existing DH system in Latvia. The efficiency of a large-scale solar collector field can be increased by lowering DHN temperature regimes. Schmidt et al. [12] presented an analysis of a DH 
system with solar heating and heat pumps (HPs) using geothermal energy for a new residential area. Low potential geothermal heat was explored as a heat source for a LTDHN in $[13,14]$. David et al. [15] identified that existing large-scale HPs are used to utilise various types of low-temperature heat sources, such as sewage water, surface water, industrial waste heat, geothermal heating, and flue gas. Sewage water, as well as surface water from rivers, lakes, and the sea, can be considered a stable heat source despite its generally lower temperatures. Large-scale HPs that use seawater as heat source to generate heat for the DHN were studied by $[16,17]$.

If a LTDHN supplies heat generated from fossil fuels, it has a smaller impact on the environment than conventional DHNs due to lower heat loss resulting in a reduced use of fossil fuels. Another advantage is that lower return temperatures have a positive effect on heating plants, increasing exhaust gas heat recovery $[18,19]$.

Developers of new urban areas have a variety of heat supply options, such as connecting to the existing DHN, installation of a small local DHN, individual heating solutions or the integration of renewable energy sources, such as seawater, solar heat, etc.

Various studies analysed different strategic opportunities for decision-making associated with the new area's heating supply. Kanta et al. [20] presented an evaluation of 11 alternative heating systems for the Harmaakallio area in Loviisa, Finland, using multi-criterial decision analysis. The analysis included economic, environmental, social, technological, and usability criteria. Mahapatra [21] compared DH with other residential heating alternatives in the Växjö municipality (Sweden) focusing on the following indicators: average specific energy consumption, primary energy consumption, and $\mathrm{CO}_{2}$ emissions. Ristimäki et al. [22] compared various DH configurations for heat distribution in the Härmälänranta district located in Tampere, Finland, by combining life-cycle and life-cycle cost analyses. Schmidt et al. [12] compared alternative scenarios for the LTDHN in the residential area Zum Feldlager located in Kassel, Germany. Primary energy consumption, $\mathrm{CO}_{2}$ emissions and space requirements for the installation of the supply components were chosen as technical indicators; annual heating costs, price stability, and amortisation period were used as economic indicators. Usability and the rate of innovation were also taken into account.

This research paper explores a case study, where alternative scenarios of an area's heat supply options are analysed from the technical point of view and are compared using economic and environmental indicators. The development of a new residential area in Kopli consists of two stages. During the first stage of the development process, it is planned that there will be 21 multi-family residential buildings with floor heating and total heat demand of $1.2 \mathrm{MW}$. During the second stage of the development process, it is planned that both multi-family residential buildings and public buildings will be built with the total heat consumption of $4.5 \mathrm{MW}$. In this case study, the developer faced certain limitations during the first development stage due to the used energy sources. According to the preliminary regional plan, there is no possibility to install a biomass boiler or a HP during the first stage. Instead, the following three options were considered

- Connection to the existing $\mathrm{DH}$ system of the surrounded area with a supply and return temperature of $95^{\circ} \mathrm{C}$ and $55^{\circ} \mathrm{C}$, respectively.

- Installation of a new gas boiler with a temperature schedule of $80^{\circ} \mathrm{C} / 40^{\circ} \mathrm{C}$.

- Installation of a new gas boiler with a temperature schedule of $60^{\circ} \mathrm{C} / 35^{\circ} \mathrm{C}$ during the first planning stage and the installation of a seawater HP during the second stage.

The originality of this paper is evidenced by the fact that it provides an analysis of an integrated solution involving both traditional (gas boilers) and sustainable (seawater HP) heat generation technologies. Since the process of the development and transition towards the new low-temperature networks is rather long and filled with obstacles, the integrated approach examined in this paper could prove to be useful for the overall development of $\mathrm{DH}$.

The following section describes the method used for analysing the different $\mathrm{DH}$ scenarios. In the third section of this paper, the case study is discussed, along with the results and their analysis. The fourth section provides a discussion and conclusions.

\section{Method}

When the developer decides to use $\mathrm{DH}$ solutions for the newly developed areas, it is important to choose sustainable solutions to reduce the environmental impact. Therefore, it may be relevant to determine economic and environmental indicators to compare various $\mathrm{DH}$ development possibilities in the area. The considered scenarios for this study were limited by external conditions, such as regional planning, energy sources and their availability, and time restrictions due to the developer implementation plans. 


\subsection{Scenarios}

The following three scenarios have been analysed from technical, economic and environmental points of view.

Scenario A: the new DHN of the development district will be connected to the existing large-scale DHN of Tallinn. The temperature schedule for this network is $95^{\circ} \mathrm{C} / 55^{\circ} \mathrm{C}$, which is quite high, but typical for Estonia and Tallinn in particular.

Scenario B: a local boiler (natural gas-fired) will be installed, and a small local high-temperature DHN will be constructed with a temperature schedule of $80^{\circ} \mathrm{C} / 40{ }^{\circ} \mathrm{C}$. Using wood chips as fuel was not an option due to the lack of land for the boiler house construction (wood chip storage requires additional space), and due to the strict rules enforced by the local municipality (during the project development stage only gas-fired boilers were allowed in this region).

Scenario C: installation of a seawater HP and a gas-fired boiler. The seawater HP would provide the base load for the area and the boiler would cover the intermediate and peak load. Additionally, a low-temperature $\mathrm{DHN}$ will be installed with a temperature schedule of $60^{\circ} \mathrm{C} / 35^{\circ} \mathrm{C}$.

If Scenario A is realised, the new residential area will be connected to the existing DHN. The local $\mathrm{DH}$ operator Adven Eesti AS offered this solution. The existing DHN consists mainly of old $\mathrm{DH}$ pipelines (in concrete ducts), with an average lifetime of 25 years and $15 \%$ heat loss. The distance to the existing network is $300 \mathrm{~m}$. A Scenario A-based solution is typical for Estonia and Tallinn, new customers connect to the existing high-temperature DHN due to a wide range of DH use. In addition, developers themselves are interested in outsourcing heat production and distribution.

For Scenario B, it was assumed that three gas boilers will be installed in a separate building with all the required equipment (chimney, water and sewage supply, natural gas supply, electricity supply and communication network). The following gas boilers will be installed: two Viessmann Vitoplex 200 gas boilers with a capacity of $1950 \mathrm{~kW}$ each, and a smaller $560 \mathrm{~kW}$ Viessmann Vitoplex 200 boiler. Flue gas condensers (Viesmann Vitotrans 300) will be installed for the big boilers, as well as water treatment facilities and DHN pumps. The dimensions of the boiler house are as follows: length $-13.5 \mathrm{~m}$, width $-6.6 \mathrm{~m}$, and height $-2.95 \mathrm{~m}$. The height of the flue gas chimney is $13.45 \mathrm{~m}$.

If scenario $C$ is realised, then both the gas boiler and a large-scale HP will be installed. The characteristics of the boiler will be the same as for Scenario B, but in this case two boilers will be installed: Viessman Vitoplex with capacity $1950 \mathrm{~kW}$ and a smaller $560 \mathrm{~kW}$ Viessmann Vitoplex 200 boiler. In addition to the gas boiler, it is planned to install a large-scale two-stage seawater HP that uses ammonia as a refrigerant with an open intercooler. The HP will be located $100 \mathrm{~m}$ from the sea and $200 \mathrm{~m}$ away from the gas-fired boiler house. A two-stage HP ensures sufficiently low discharge temperatures of the compressors without damaging the equipment, lower pressure ratio and a better coefficient of performance (COP) than a single-stage cycle. Ammonia is a natural refrigerant that has zero global warming potential and no ozone depletion potential [23].

Technical parameters related to the three scenarios are given in Table 1 . The gas-fired boilers have a flue gas condenser. According to [17], DH can improve the boiler efficiency by condensing the flue gas from the combustion. The lower the return temperature received from the grid is, the more heat can be extracted from the flue gas. Based on the calculations presented in [19], it was assumed that a decrease in return temperature from $40^{\circ} \mathrm{C}$ to $35^{\circ} \mathrm{C}$ could improve the efficiency of the gas boiler from $90 \%$ to $91 \%$.

Table 1: Technical parameters of case study scenarios

\begin{tabular}{|c|c|c|c|c|c|}
\hline Scenario & $\begin{array}{l}\text { Supply/return } \\
\text { temperature, } \\
{ }^{\circ} \mathrm{C}\end{array}$ & Type of fuel & Heat production units & Heat capacity, MW & Efficiency, - \\
\hline A & $95 / 55$ & Natural gas & $\begin{array}{c}1^{\text {st }} \text { stage: old boiler } \\
2^{\text {nd }} \text { stage: new local boiler }\end{array}$ & $\begin{array}{c}20 \\
2\end{array}$ & $\begin{array}{l}0.80 \\
0.86\end{array}$ \\
\hline $\mathrm{B}$ & $80 / 40$ & Natural gas & $\begin{array}{l}\text { Boiler } 1 \\
\text { Boiler } 2 \\
\text { Boiler } 3\end{array}$ & $\begin{array}{c}2 \\
2 \\
0.6\end{array}$ & $\begin{array}{l}0.89 \\
0.89 \\
0.90\end{array}$ \\
\hline $\mathrm{C}$ & $60 / 35$ & $\begin{array}{l}\text { Natural gas, } \\
\text { electricity }\end{array}$ & $\begin{array}{c}\text { Boiler } 1 \\
\text { Boiler } 2 \\
\text { Heat pump }\end{array}$ & $\begin{array}{c}2 \\
0.6 \\
2.1 \\
\end{array}$ & $\begin{array}{c}0.91 \\
0.9 \\
4.04\end{array}$ \\
\hline
\end{tabular}

For the analysis conducted in Scenario C, a thermodynamic model of a seawater HP was developed using the software Engineering Equation Solver (EES) [24]. First, a design HP model was developed for the HP dimensioning, which determined the UA values of the heat exchangers and compressor displacement rate for design conditions. The isentropic efficiencies of the compressors were 
determined from a relation for idealised conditions, as shown in [23] by equation (1), valid for screw compressors.

$$
\eta_{\mathrm{is}}=\eta_{\mathrm{is}, \max } \frac{\left(p_{H} / p_{L}\right)^{(\kappa-1) / \kappa}-1}{\pi_{i}^{(\kappa-1) / \kappa}-\frac{\kappa-1}{\kappa} \pi_{i}^{-(1 / \kappa)}\left(\pi_{i}-p_{H} / p_{L}\right)-1}
$$

where

$p_{H} / p_{L}$ is the pressure ratio;

$\pi_{i}=v_{i}^{\kappa}$ is the built-in pressure ratio;

$\kappa$ is the polytrophic exponent.

The only loss considered is due to the mismatch between the built-in pressure ratio and the actual pressure ratio. The built-in volume ratio $v_{i}$, as well as the intermediate pressure of the two-stage HP were optimized to achieve the highest COP in design conditions. Heat exchangers for the condensation process were modelled as a de-superheating, condensing and sub-cooling part, each fulfilling energy balances. Furthermore, no superheat after the evaporator was assumed due to the characteristics of ammonia as a refrigerant. A pinch point temperature difference between the refrigerant and the $\mathrm{DH}$ water of $5 \mathrm{~K}$ at the condenser inlet and sub-cooling outlet (refrigerant flow) was assumed. The design conditions and assumptions for the thermodynamic HP model can be found in Table 2. The HP design model overview is shown in the Q-T diagram and $\log (\mathrm{p})$-h diagram in Figure A.1.

Table 2: Parameters and design conditions for the HP design model

\begin{tabular}{llllll}
\hline Parameter & Value & Unit & Parameter & Value & Unit \\
\hline Supply/return temperature DH & $60 / 35$ & ${ }^{\circ} \mathrm{C}$ & $\mathrm{COP}$ & 3.82 & - \\
Heat capacity & 2.1 & $\mathrm{MW}$ & $\mathrm{UA}_{e}$ & 238 & $\mathrm{~kW} / \mathrm{K}$ \\
Heat source inlet temperature & 4 & ${ }^{\circ} \mathrm{C}$ & UA $_{c, \text { tot }}$ & 154 & $\mathrm{~kW} / \mathrm{K}$ \\
Heat source outlet temperature & 1 & ${ }^{\circ} \mathrm{C}$ & $\eta_{\mathrm{LP}}$ & 0.74 & - \\
Intermediate pressure & 6.7 & $\mathrm{bar}$ & $\eta_{H P}$ & 0.76 & - \\
Built-in volume ratio & 2.0 & - & Displacement rate (LP) & 0.47 & $\mathrm{~m}^{3} / \mathrm{s}$ \\
Compressor max. isentropic efficiency & 0.80 & - & Displacement rate & 0.32 & $\mathrm{~m}^{3} / \mathrm{s}$ \\
[23] & & & (HP) & & \\
Compressor volumetric efficiency [23] & 0.9 & - & Mass flow rate (LP) & 1.27 & $\mathrm{~kg} / \mathrm{s}$ \\
Pinch point temperature difference & 5 & $\mathrm{~K}$ & Mass flow rate (HP) & 1.53 & $\mathrm{~kg} / \mathrm{s}$ \\
\hline
\end{tabular}

The UA values of evaporator and condenser and the displacement rates of the compressors were used as input parameters for the off-design model, in which the intermediate pressure and pinch point temperature difference at the evaporator inlet were free variables and the displacement rates were used as maximum values representing full load operation. Part-load was calculated based on the ratio between the actual displacement rate and the maximum value at design conditions. In the off-design model, the COP and other parameters were calculated based on varying load and heat source temperatures.

Seawater temperatures were provided by the Estonian Weather Service [25]. Hourly data for 2016 was obtained from the station located in Pirita at the depth of $1.5 \mathrm{~m}$. The minimum permissible seawater temperature out of the evaporator was set at $-0.5^{\circ} \mathrm{C}$, considering freezing temperatures due to the salinity of the Baltic Sea (15\%o to $25 \%$ ), as reported in [26]. This may limit the heat that can be extracted during certain periods of the year when the seawater temperature is below $2.5^{\circ} \mathrm{C}$ due to the evaporator designed according to an inlet and outlet temperature difference of 3 $\mathrm{K}$.

The COP throughout the year was calculated using the thermodynamic HP model for off-design conditions, as shown in Figure 1. It can be seen that the COP fits the design conditions from December to April. During the remaining year, the COP is higher with values reaching slightly above 5 due to warm seawater temperatures in the summer. The seasonal COP, consisting of the ratio between annual supplied heat and annual consumed electricity, was 4.04 . The installed capacity of the HP was assumed to be $2.1 \mathrm{MW}$. 


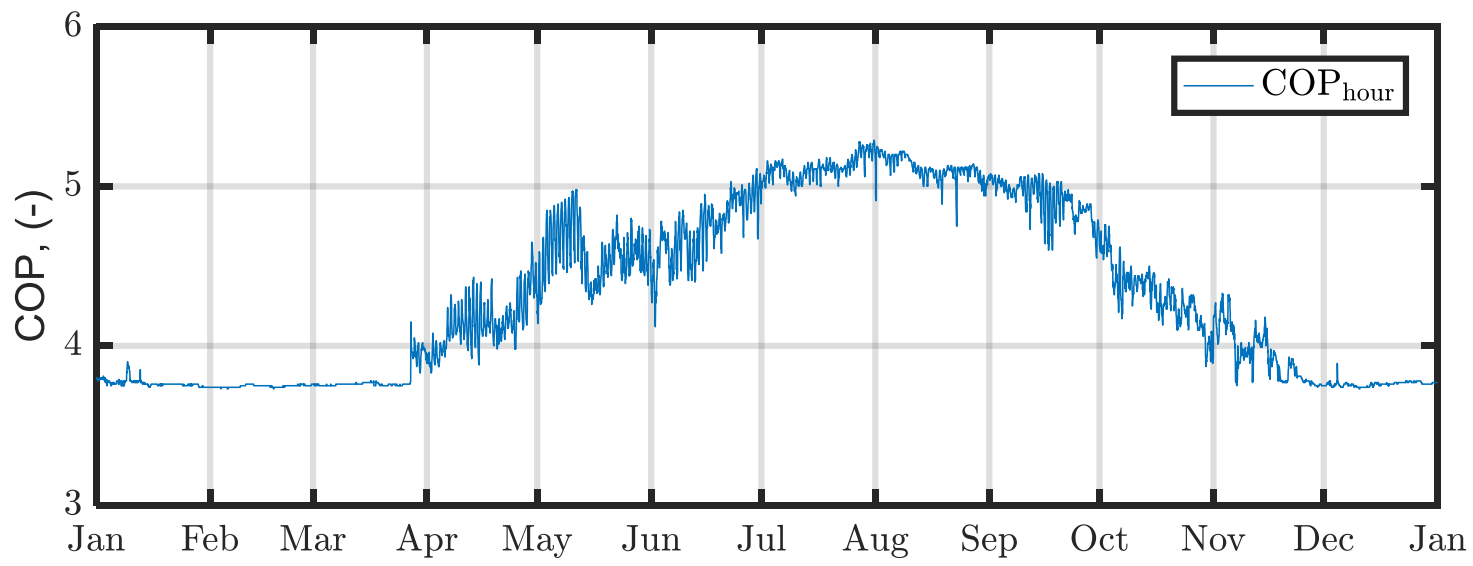

Figure 1: COP of seawater HP over the year

\subsection{Indicators}

\subsubsection{Heat loss}

The annual heat loss changed due to the reduction of transmission temperature have been considered. Absolute heat loss was compared, as heat demand is the same for all scenarios. Logstor software was used to calculate the annual heat loss, in accordance with the methodology presented by Wallenten [27].

It was assumed that the flow temperature is dependent on ambient temperature and is changing throughout the year. The only exception is the low temperature scenario, where low supply temperature is the same for both heat and summer seasons. Only heat loss associated with the newly constructed DHN was taken into account. In Scenario A, the heat loss in the existing DHN was not calculated. The relative heat loss based on outdoor temperature is also calculated for all scenarios.

\subsubsection{Primary energy consumption}

Another indicator is the primary energy (PE) consumption per unit of heat consumed. This parameter takes into account both fuel used for heat production and electricity used for the HP. Boiler energy is also taken into account. This is important due to the use of a flue gas condenser, which is affected by the return temperature.

Primary energy consumption was calculated using equation (2)

$$
\mathrm{PE}=\frac{Q_{\mathrm{NG}} \mathrm{PEF}_{\mathrm{NG}}+Q_{\mathrm{el}} \mathrm{PEF}_{\mathrm{el}}}{Q_{C}}
$$

where

$Q_{N G}$ is annual natural gas consumption by boiler, MWh;

$Q_{\mathrm{el}}$ is annual electricity consumption, MWh;

$Q_{C}$ is annual heat consumption;

$P E F_{\text {el }}$ is primary energy factor for electricity production in the country;

$\mathrm{PEF}_{\mathrm{NG}}$ is the primary energy factor for natural gas.

Annual gas consumption is calculated using equation (3)

where

$$
Q_{N G}=\frac{Q_{\mathrm{PNG}}}{\eta_{\mathrm{NG}}}
$$

$Q_{P N G}$ is annual heat produced by the boilers;

$\eta_{N G}$ is boiler energy efficiency.

Electricity consumption is calculated using equation (4)

$$
Q_{P}=Q_{\mathrm{el}, \mathrm{HP}}+Q_{\mathrm{el}_{P}}
$$

where

$Q_{e l_{H P}}$ is electricity consumed by the HP;

$Q_{e l_{P}}$ is electricity required for pumping; 
The HP electricity consumption was determined by solving the following equation:

$$
Q_{\mathrm{el}, \mathrm{HP}}=\frac{Q_{\mathrm{PHP}}}{\mathrm{COP}}
$$

where

$Q_{P_{\mathrm{HP}}}$ is the heat produced by the HP, MWh

COP is the hourly calculated COP.

It should be noted that due to the size of the DHN and high pump performance efficiency, changes in electricity consumption caused by an increase in flow were negligible. The same electricity consumption for pumping was assumed for all scenarios. The following PEFs were used for the calculations: 1 for natural gas and 2 for electricity consumption [28].

\subsection{3. $\mathrm{CO}_{2}$ emissions}

This indicator is related to the previous indicator and is based on fuel and energy sources used for heat production. The $\mathrm{CO}_{2}$ emission factor for natural gas is $0.201 \mathrm{tCO}_{2} / \mathrm{MWh}$ and the one for electricity production in Estonia is $0.95 \mathrm{tCO}_{2} / \mathrm{MWh}$ [29]. The high emission factor for electricity generation was determined by the high proportion of local oil shale in electricity production of the country [30]. Due to this fact, Estonia has one of the highest $\mathrm{CO}_{2}$ emission rates per capita in the world [31].

\subsubsection{Investment costs}

The investment structure is different for each scenario. The mandatory component for all three scenarios is the construction of a new small-scale DHN. Network construction investments include the following:

- $\quad$ DH pipeline material

- Construction of DH pipelines

- Excavation

- Other construction costs

The installation of the DHN can be made when the new development area will be built. Therefore, costs can be saved related to the reconstruction of the pavement.

For scenario A, additional investments required for the interconnection with the existing DHN were also assumed. No investments are required for own heat production units (gas-fired boiler house, HP), however, the developer will not have the opportunity to produce and sell heat in this area.

For scenarios $B$ and $C$, constructing and installing the new boiler house was one of the main investments. The data on investment costs for gas boilers and the DHN construction was obtained from boiler manufacturers and DHN construction companies. The investment costs included the price of boilers, as well as the construction of the boiler house with all the necessary equipment. The dimensions of the boiler house were the same for scenarios B and C, regardless of the boiler capacity This means that the construction and land use costs associated with the boiler house are the same for both scenarios.

For scenario C, the HP investment costs were based on the correlation found in Pieper et al. [32]. Since no costs for seawater HPs were available at the time, the costs for sewage water HPs were used instead. The fixed investment for the HP was assumed to be $484.000 \mathrm{EUR}$, and the variable investments were assumed to be 550.000 EUR per MW. Furthermore, access to seawater at a 200 $m$ distance requires additional investment costs for piping. The HP is planned to be installed on the site otherwise planned to be used as a park, so no additional land investment costs apply.

\subsubsection{Costs of heat}

For Scenario A costs of heat depend on the price of $\mathrm{DH}$, which is set by the Estonian Competition Authority for the DH region. For autumn 2018, the price for the considered region was 56.65 EUR/MWh. It was assumed that the price may increase in the future, since heat is being generated by a natural gas-fired boiler for the existing DHN, which has significant network heat losses. Consequently, no revenue from $\mathrm{DH}$ production was generated for scenario $\mathrm{A}$, because the generation and distribution of $\mathrm{DH}$ was outsourced. 
The cost of heat includes the cost of operation, maintenance, fuel, and electricity. Additionally, a levelised energy cost is added, i.e., the cost of heat produced in MWh by an asset (boilers, heat pumps) over its lifetime, with investment costs taken into account [33].

For scenario B costs of heat depend mainly on the price of natural gas set for Estonian customers. In 2018, the price was $35 \mathrm{EUR} / \mathrm{MWh}$, but this price is likely to increase in the future. This is expected, because the consumption of natural gas in Estonia is declining every year since 2008, because of the construction of new boiler houses based on local biomass. Furthermore, the BalticConnector project is being developed, which aims to interconnect the Estonian and Finnish gas transmission networks. Both will have an impact on the tariff of the transmission system operators (TSO). Finally, the Estonian government plans to increase excise duty for using natural gas as a fuel. It is predicted that the price of natural gas will increase by $20 \%$ in 10 years, resulting in 42 EUR/MWh [34]. Electrical supply for pumps in boiler houses was assumed to be $12 \mathrm{kWh}$ electricity for $1 \mathrm{MWh}$ of heat, O\&M costs were assumed to be 6,000 EUR/year and other costs, including $\mathrm{CO}_{2}$ taxes, 10,000 EUR/year. In addition, the net present value (NPV) was calculated for 10 years and the payback period (PBP) for an internal rate of return (IRR) of $7 \%$, both considering discounted cash flows and heat sold to the customers at 55 EUR/MWh.

For scenario $\mathrm{C}$, prices for gas-fired boiler houses and the gas price were the same as for scenario $\mathrm{B}$. O\&M costs were higher, because of additional costs for HP operation and were assumed as 44,000 EUR/year. The operational costs of the HP were obtained from [35]. The costs for electricity consumption of the HP and pumping were calculated for the first year using the hourly Nord Pool prices from 2017 [36]. In addition, energy tax, renewable energy taxes, transmission and capacity fee were added. Forecasts for natural gas and electricity prices were taken into account, calculating costs of heat $[34,37]$. The NPV and PBP were calculated for the same assumptions as for scenario B.

\section{Case study}

Over the past decade, many new city districts have been built in Estonia, including Pärnaõue and Liivaoja (Tallinn), Kvissental (Tartu), Uusmäe (Saku), Merikotka (Kuressaare), and the interest in developing new residential districts continues to grow. Typically, connecting to an existing hightemperature DH system is used as a heating solution. This is usually done, because municipalities determine the DH regions in which connecting to DH is mandatory, according to Estonia's District heating regulation act. This study presents an analysis of alternative heat supply scenarios for the newly developing subdistrict of Kopli, Tallinn. According to the present legislation and regulations, the developer could decide either to connect to an existing DHN or to construct a new small DHN. The distance to the existing DHN, which is owned by Adven Eesti AS, is $300 \mathrm{~m}$. The development of the Kopli subdistrict consists of two stages. 21 multi-family residential buildings with floor heating and a total heat demand of $1.2 \mathrm{MW}$ are planned during the first stage of development. By the end of the second development stage, 49 multi-family residential buildings and 4 public buildings with a total heat demand of $4.5 \mathrm{MW}$ are planned. A schematic map of the area can be seen in

Figure 2. 


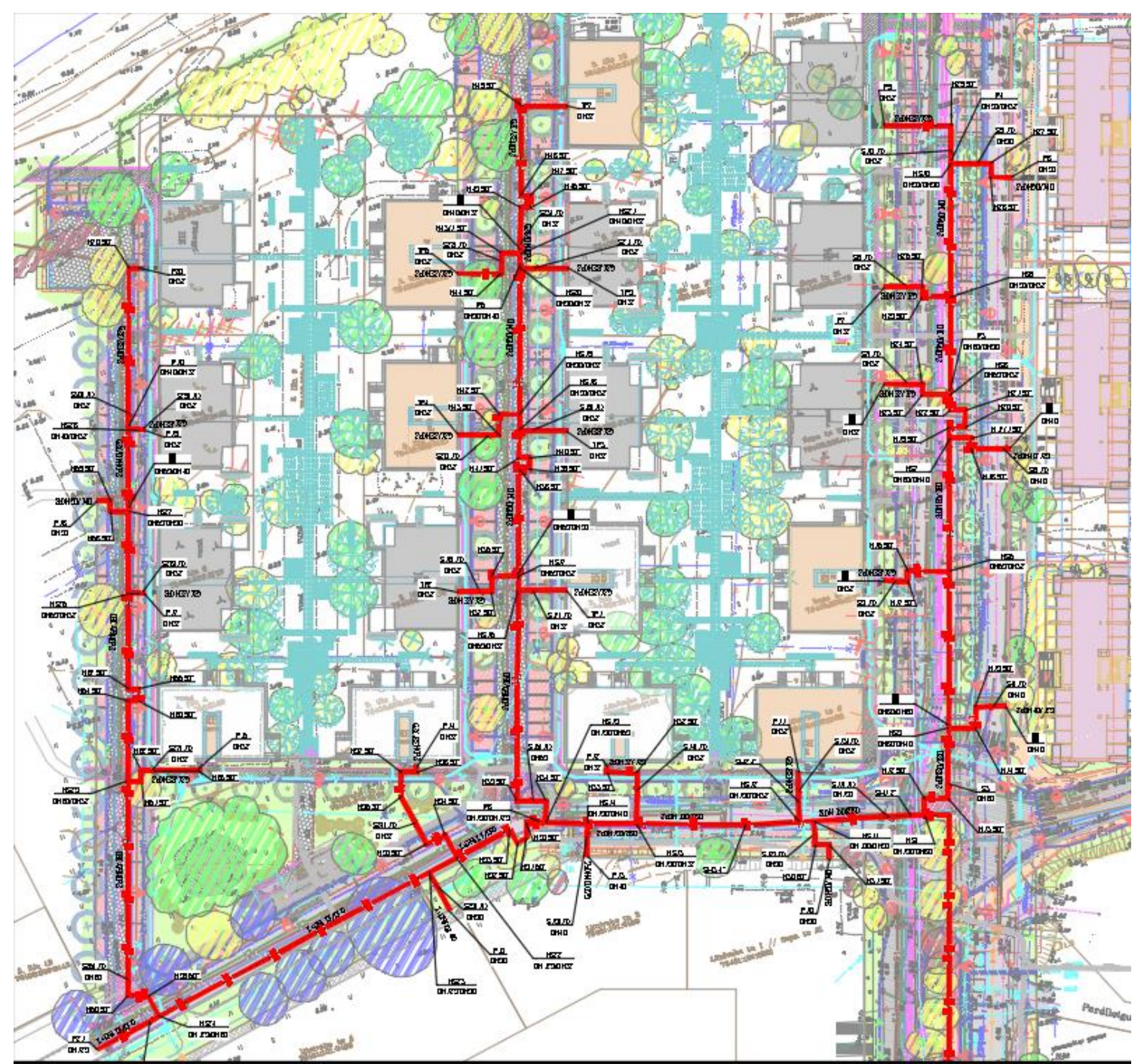

Figure 2: Schematic map of the case study area, a subdistrict of Kopli, Tallinn

The new residential area will have very compact two- and four-storey apartment buildings. In addition, there will be a kindergarten, a school, a gym and a shopping mall. It was assumed that all buildings will have a specific space heating demand of $45 \mathrm{kWh} / \mathrm{m}^{2} / \mathrm{a}$ and a specific domestic hot water (DHW) demand of $730 \mathrm{kWh} / \mathrm{a}$. Floor heating systems will provide heating in all buildings. Each building will have hot water storages installed. Each tank has a water volume of 3000 I. The overall heat demand was calculated by the developer of the area.

The heat demand curve for the whole development area based on the normalised annual outdoor temperature is shown in Figure 3. It may be seen that the heat load in summer is rather high and constitutes almost half of the maximum heat load. This is because of the energy-efficient buildings with floor heating, which results in a very low space heating demand in winter. 


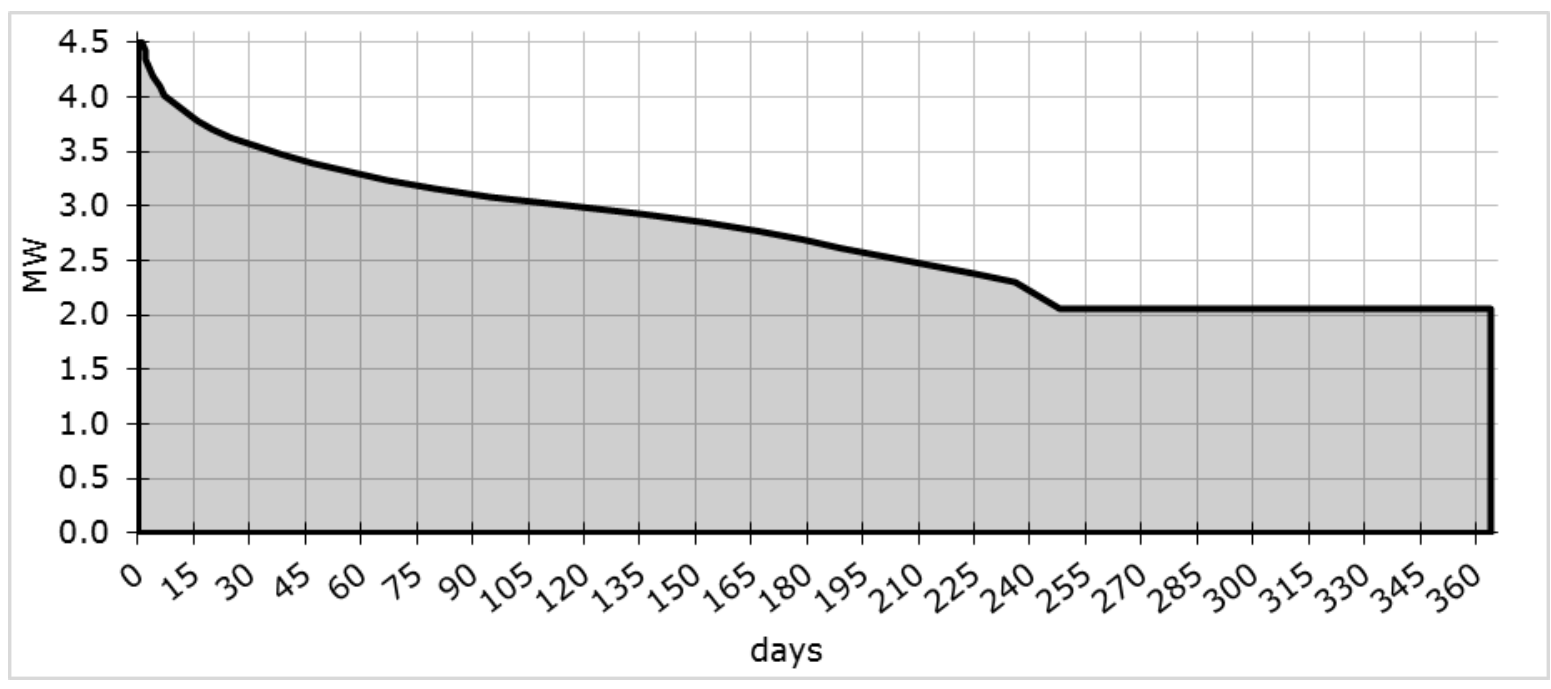

Figure 3: Heat load duration curve for the case study

The gas supply infrastructure (with the required gas boiler pressure of 5 bar) are located close to the district (20 $\mathrm{m}$ to the existing gas pipeline). Pipe parameters used for the heat loss calculations are given in Table 3.

Table 3: Pipe parameters

\begin{tabular}{ll}
\hline Depths & $1 \mathrm{~m}$ \\
Pipe length & 1. stage: $1,140 \mathrm{~m}$ \\
& 2. stage: $1,166 \mathrm{~m}$ \\
Diameters & DN32/125, DN40/125, DN50/140, DN65/160, DN80/180, \\
& DN100/225, DN125/250, DN150/280, DN200/355 \\
Insulation & $0.023 \mathrm{~W} / \mathrm{mK}-0.025 \mathrm{~W} / \mathrm{mK} ; 2^{\text {nd }}$ class
\end{tabular}

The heat load duration curve for Scenario $C$ is shown in Figure 4.

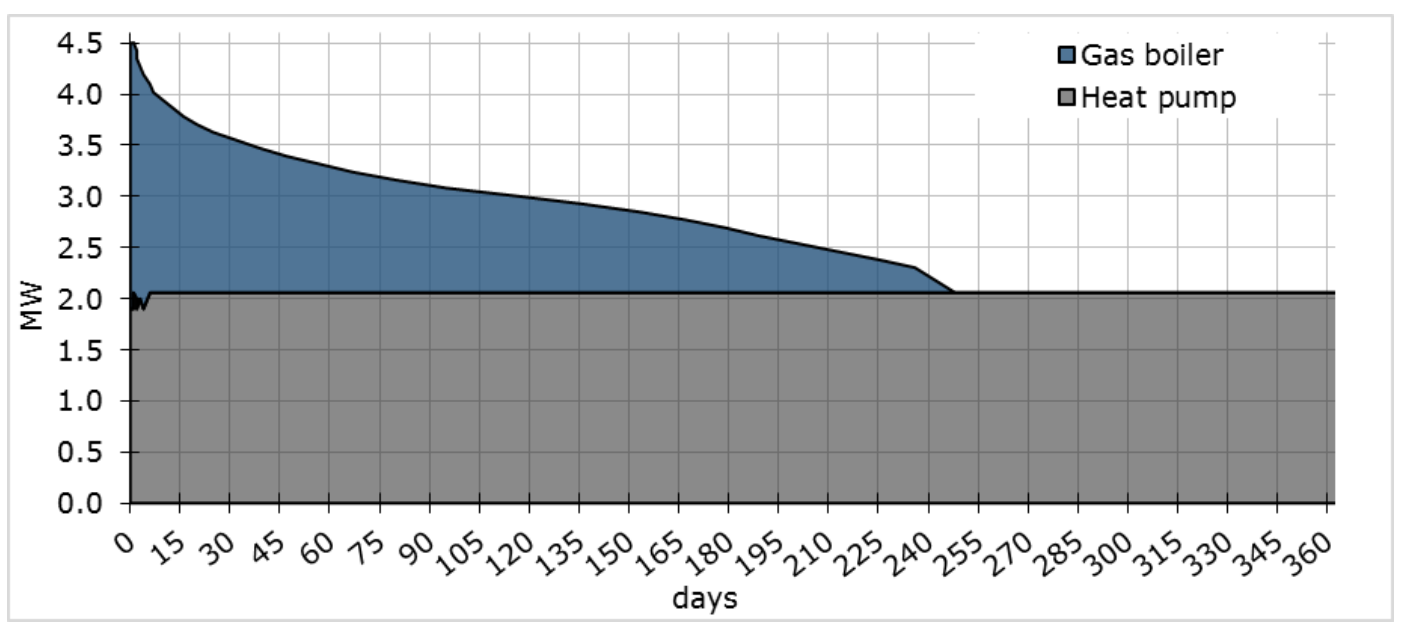

Figure 4: Heat load duration curve for C scenario of case study

\section{Results}

Based on the methodology presented earlier, the heat loss, PE consumption, $\mathrm{CO}_{2}$ emissions, investment costs and costs of heat for the three different scenarios are shown in the following.

4.1. Heat loss 
The annual heat loss for the different scenarios can be found in Table 4. As shown, the absolute and relative heat loss is the lowest for scenario $C$ and the highest for scenario $A$.

Table 4: Network heat loss for the three different scenarios

\begin{tabular}{lll}
\hline Scenario & Annual heat loss (MWh) & Relative heat loss \\
\hline A & 913 & $4.0 \%$ \\
B & 762 & $3.5 \%$ \\
C & 653 & $2.9 \%$ \\
\hline
\end{tabular}

The relative heat loss for different supply and return temperatures, depending on the outdoor temperature, can be found in Figure 5.

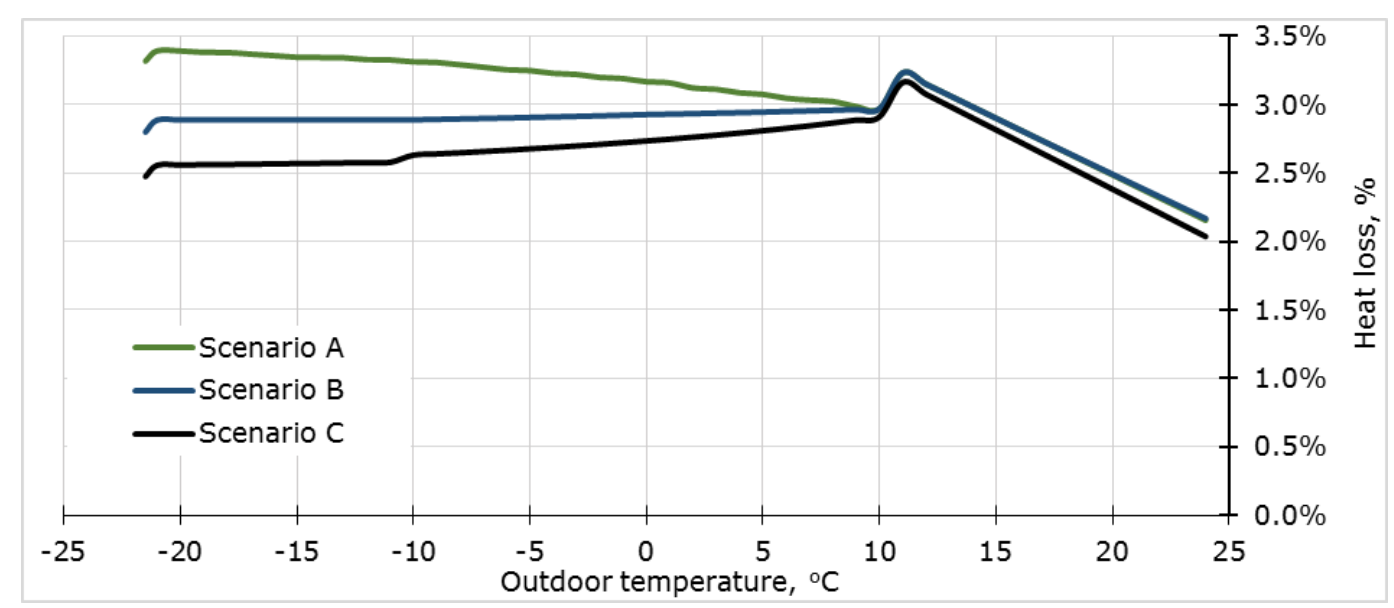

Figure 5: Relative heat losses in small DHN for the scenarios

The relative heat loss increased for an outdoor temperature of $10^{\circ} \mathrm{C}$, because space heating was not required in this period, and the heat demand became lower. If the outdoor temperature increased further, the absolute heat losses decreased, but the heat load for DHW remained the same.

\subsection{PE consumption and $\mathrm{CO}_{2}$ emissions}

The PE consumption per unit of heat consumed and the $\mathrm{CO}_{2}$ emission factors are shown in Figure 6.

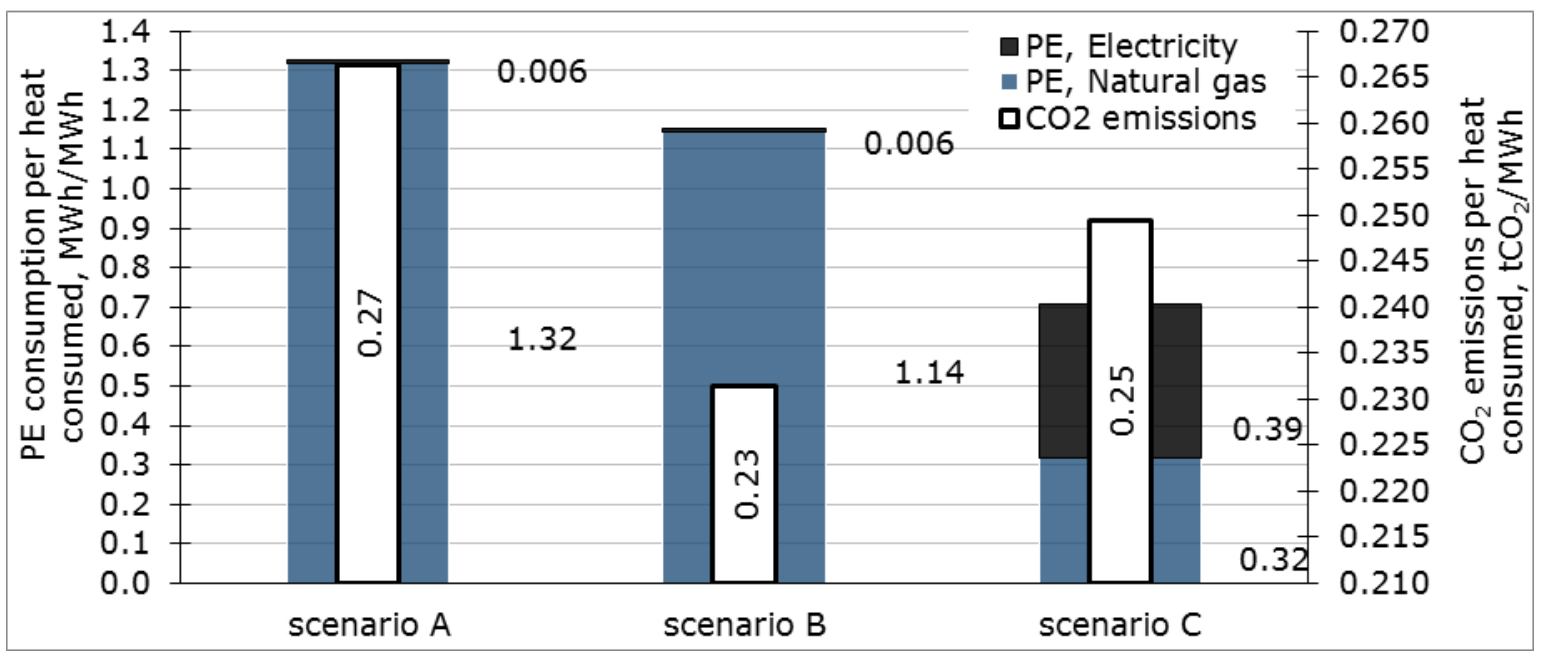

Figure 6: PE consumption and $\mathrm{CO}_{2}$ emissions for heat production of the three scenarios

Scenario $A$ has the highest PE consumption, which can be explained by higher heat losses in the small local DHN, along with additional losses due to the distance of $2.5 \mathrm{~km}$ between the existing 
boiler house and the small DHN. In addition, the boiler efficiency in scenario A is lower than in the other scenarios. The PE consumption per unit of heat consumed is much lower for scenario $\mathrm{C}$. PE required for producing heat from natural gas is more than 3 times lower in this case. Additional PE is required for the electricity consumption of the HP, as shown.

The highest $\mathrm{CO}_{2}$ emissions per unit of consumed heat were found for scenario $A$, due to high heat loss in the existing DHN and lower boiler efficiency. In scenario $\mathrm{C}$, the $\mathrm{CO}_{2}$ emissions are high, too. As mentioned above, the $\mathrm{CO}_{2}$ emission factor for electricity is very high in Estonia. This is why even a small amount of electricity used for the HP will dramatically increase the $\mathrm{CO}_{2}$ emissions. The lowest $\mathrm{CO}_{2}$ emissions occurred for Scenario $\mathrm{B}$, because heat losses are lower and no electricity was used for the heat production.

It is also possible to use a "Green energy" electricity package from the electricity provider, which means that the consumed electricity would be from renewable energy sources (biomass, wind, hydro) and not from a mix of sources: oil shale, biofuels, waste, wind or water. The costs for electricity consumption would be higher in this case.

\subsection{Investment costs}

The investments costs are shown in Figure 7.

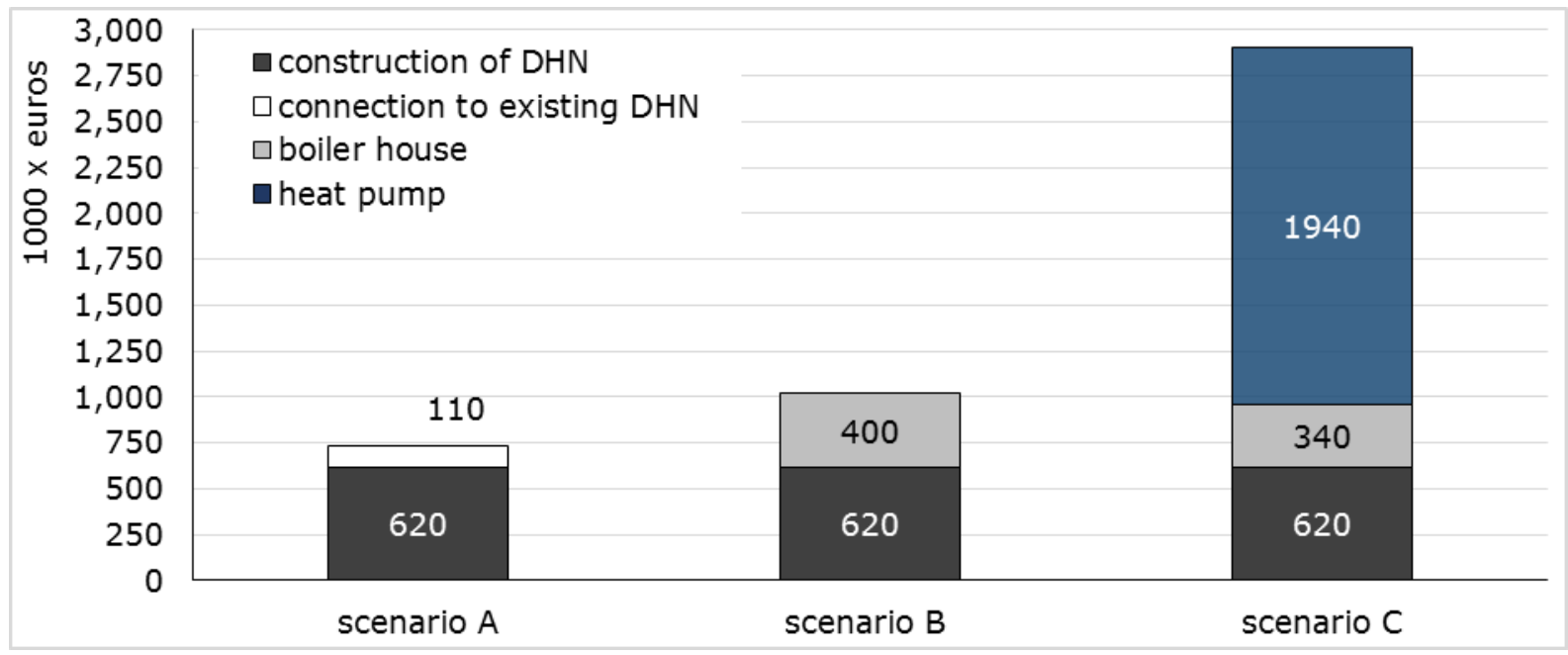

Figure 7 : Investments structure for scenarios

As it can be seen in Scenario A, the largest portion of the investments is associated with the new DHN layout. The investment costs for scenario $B$ are higher, because a new gas-fired boiler house has to be constructed and connected to the DHN. The investment costs are the highest for scenario $\mathrm{C}$, because of the high costs associated to the HP.

\subsection{Cost of heat}

The costs of heat were not calculated for Scenario A. For this case price is set by Competition Authority. Currently, it is 56,65 EUR/MWh, and it will increase in the future due to increase in natural gas costs (based on the fuel $\mathrm{DH}$ uses).

For scenario B and C, the calculated costs of heat for 2019 were 45.51 EUR/MWh and 38.86 EUR/MWh, respectively. Forecasts of the costs for heat, taken into account investment costs, are presented in Figure 8. Despite the high investment costs for scenario $C$, the costs of heat are the lowest, because of the high SCOP of the HP and the low electricity costs. 


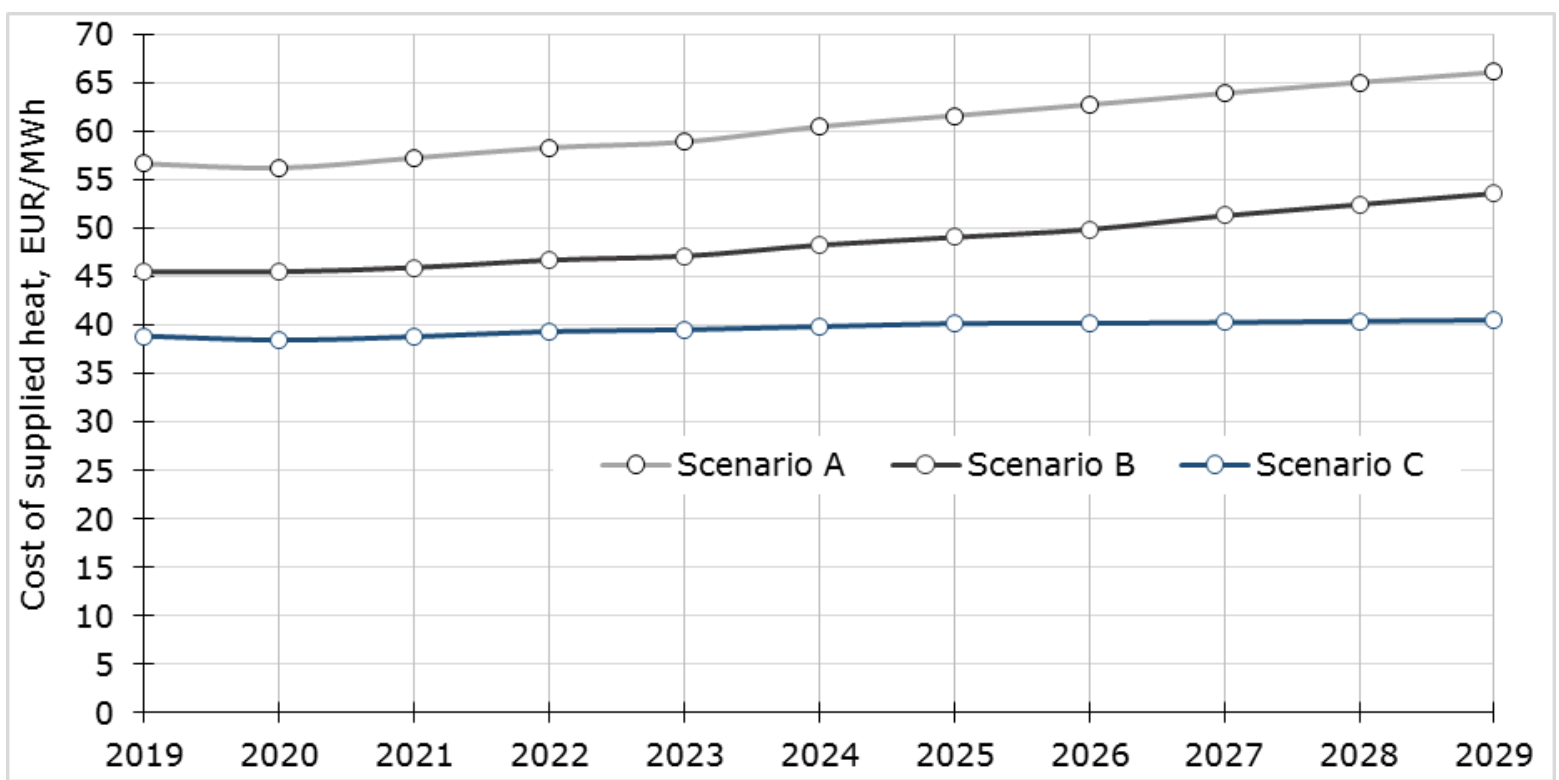

Figure 8: Forecast for costs of heat

Taking into account investments and costs of heat, as well as the projected income from heat sales, the discounted cash flows were calculated, and these results are presented in Figure 9. Scenario B offers a $100 \%$ return on investment in 4 years, as opposed to scenario C's more than 5 years. In the long run, heat production under scenario $C$ will bring more revenue. This is because the overall resource efficiency for heat production is much higher, as well as gas prices rise faster than electricity prices.

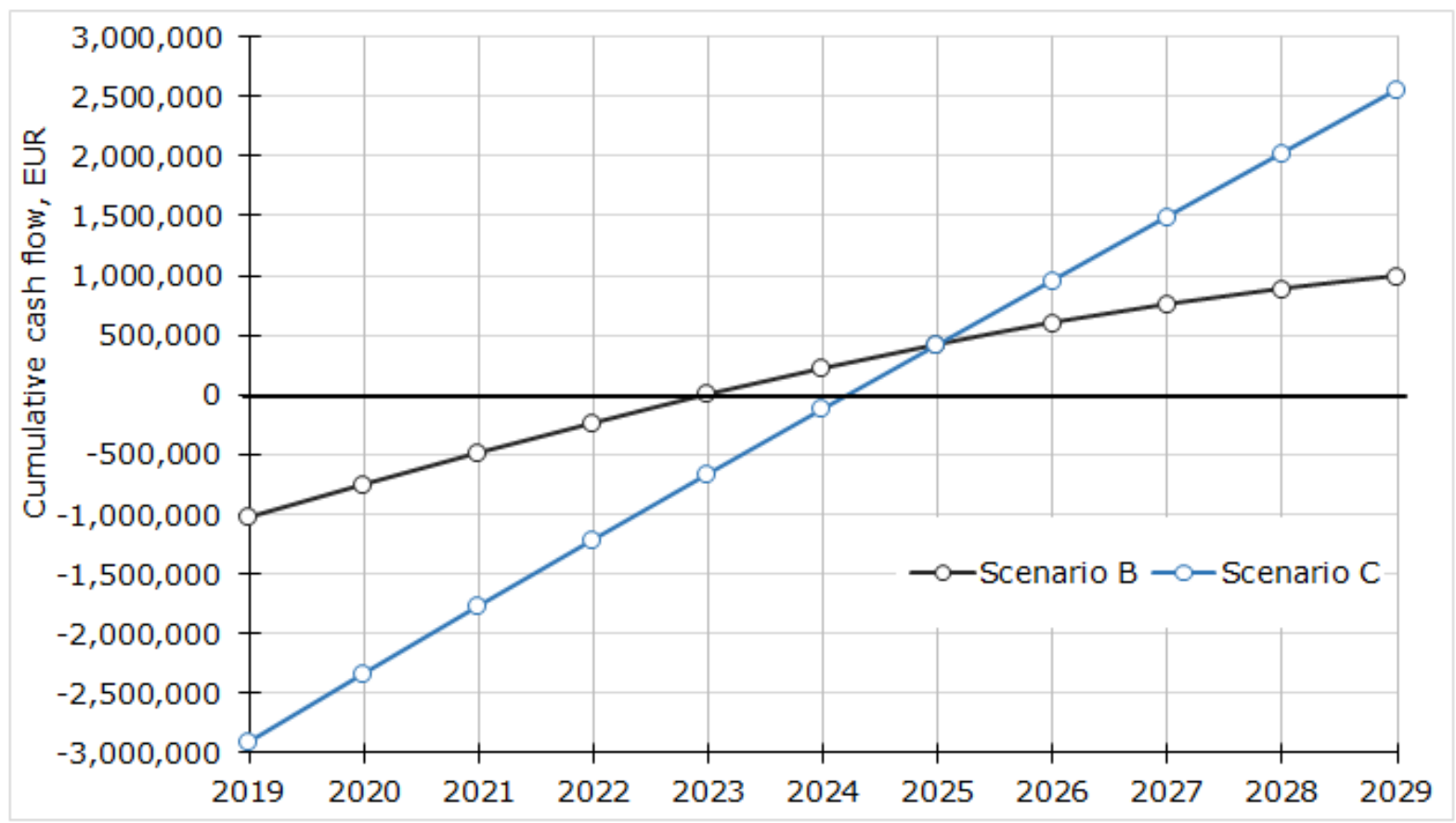

Figure 9: Cash flow for Scenario B and Scenario C

The NPV after 10 years for Scenario B was calculated as 1.000.000 EUR; however, for scenario C the NPV after 10 years was determined as 2.600 .000 EUR. This means that scenario $C$ is more feasible and promising than the other scenarios. 


\section{Discussion and conclusions}

The main barriers to the DH system development are associated with the old system's infrastructure, consumer heating devices, high building heating demand, etc. These barriers do not arise during the construction of a new residential area. The new residential area with new energy-efficient multifamily buildings with floor heating and heat recovery ventilation provides an excellent opportunity to supply heat via modern sustainable DHNs, using renewable and low potential waste heat sources.

This research paper presents the case study for such residential area, where all above mentioned conditions are met. Three heat supply scenarios have been analysed: residential area connected to the existing DHN, with a gas-fired boiler; high-temperature DHN with a small gas-fired boiler; lowtemperature DHN with a gas-fired boiler and a large-scale HP. It should be considered, that for this analysis, only the assumptions, associated with the implementation of this particular project were taken into account. For instance, it is assumed that the heat boiler station will be exactly the same in the case of two or three boilers. Another example is that the land where the HP is to be installed is owned by the developer. It is important to keep in mind that for other projects the conditions may differ. For the evaluation of these scenarios, the following indicators have been applied: heat loss, primary energy consumption per unit of heat consumed, $\mathrm{CO}_{2}$ emissions per unit of heat consumed, investments, NPV, payback period, and costs of heat. Due to the specific characteristics of Estonia, the $\mathrm{CO}_{2}$ emission factor is very high for electricity production. This explains why the scenario with the HP had the highest $\mathrm{CO}_{2}$ emissions per unit of heat consumed. The NPV indicates that the optimal solution for this project would be to install a large-scale HP and a low-temperature DHN (scenario C). Besides when natural gas price will rise, scenario $C$ will be more competitive. However, even if all of the aforementioned prerequisites are present other heat generation units are considered by the developer to be the primary options (existing high-temperature DHNs or high-temperature boiler houses).

Due to the lack of LTDHNs in Estonia, it is difficult to develop new projects with the established temperature schedule $60^{\circ} \mathrm{C} / 35^{\circ} \mathrm{C}$ for the following reasons:

- Developers fear that the lack of such experience in Estonia will lead to problems arising during the operation of the network and production units, for example, Legionella pneumophila, lack of available capacity for future clients (due to the smaller temperature difference between supply and return temperature), etc.

- Existing boiler house manufacturers actively lobby their interest in consumers continuing to utilise boilers that generate high temperature heat $\left(80^{\circ} \mathrm{C}\right.$ or above). Low-temperature boilers are specific, need specific materials and are not commonly available on the Estonian market.

- The investment costs of HPs are quite high compared to connecting to the existing DHN or a local boiler house.

To increase the likelihood of the LTDHN development in Estonia, it should be widely promoted and more studies have to be conducted, and information on the specifics of such networks should be made available to all possible stakeholders, i.e. designers, developers, constructors, local municipalities, engineers, boiler vendors.

\section{References}

[1] Lund H, Werner S, Wiltshire R, Svendsen S, Thorsen JE, Hvelplund F, et al. 4th Generation District Heating (4GDH). Integrating smart thermal grids into future sustainable energy systems. Energy 2014;68:1-11. doi:10.1016/j.energy.2014.02.089.

[2] B.Elmegaard, T.S.Ommen, M.Markussen JI. Integration of space heating and hot water supply in low temperature district heating. Energy and Buildings 2016;124:255-64. doi:10.1016/j.enbuild.2015.09.003.

[3] Dalla Rosa A, Li H, Svendsen S. Method for optimal design of pipes for low-energy district heating, with focus on heat losses. Energy 2011;36:2407-18. doi:10.1016/j.energy.2011.01.024.

[4] Li H, Svendsen S. Energy and exergy analysis of low temperature district heating network. Energy 2012;45:237-46. doi:10.1016/j.energy.2012.03.056.

[5] Köfinger M, Basciotti D, Schmidt RR, Meissner E, Doczekal C, Giovannini A. Low 
temperature district heating in Austria: Energetic, ecologic and economic comparison of four case studies. Energy 2016;110:95-104. doi:10.1016/j.energy.2015.12.103.

[6] Rämä M, Sipilä K. Transition to low temperature distribution in existing systems. Energy Procedia 2017;116:58-68. doi:10.1016/j.egypro.2017.05.055.

[7] Nord N, Kristine E, Nielsen L, Kauko H. Challenges and potentials for low-temperature district heating implementation in Norway. Energy 2018;151:889-902.

doi:10.1016/j.energy.2018.03.094.

[8] Volkova A, Mašatin V, Siirde A. Methodology for evaluating the transition process dynamics towards 4th generation district heating networks. Energy 2018;150:253-61.

doi: 10.1016/j.energy.2018.02.123.

[9] Jangsten M, Kensby J, Dalenbäck JO, Trüschel A. Survey of radiator temperatures in buildings supplied by district heating. Energy 2017;137:292-301.

doi:10.1016/j.energy.2017.07.017.

[10] Paiho S, Reda F. Towards next generation district heating in Finland. Renewable and Sustainable Energy Reviews 2016;65:915-24. doi:10.1016/j.rser.2016.07.049.

[11] Soloha R, Pakere I, Blumberga D. Solar energy use in district heating systems . A case study in Latvia. Energy 2017;137:586-94. doi:10.1016/j.energy.2017.04.151.

[12] Schmidt D, Kallert A, Orozaliev J, Best I, Germany A. Development of an Innovative Low Temperature Heat Supply Concept for a New Housing Area. Energy Procedia 2017;116:3947. doi:10.1016/j.egypro.2017.05.053.

[13] Carotenuto A, Luca G De, Fabozzi S, Figaj RD. Energy Analysis of a Small Geothermal District Heating System in Southern Italy. International Journal of Heat and Technology 2016. doi:10.18280/ijht.34S246.

[14] Aslan A. Effects of different operating conditions of Gonen geothermal district heating system on its annual performance. Energy Conversion and Management 2014;79:554-67. doi:10.1016/j.enconman.2013.12.066.

[15] David A, Mathiesen BV, Averfalk H, Werner S, Lund H. Heat Roadmap Europe : Large-Scale Electric Heat Pumps in District Heating Systems 2017:1-17. doi:10.3390/en10040578.

[16] Zhen L, Lin DM, Shu HW, Jiang S, Zhu YX. District cooling and heating with seawater as heat source and sink in Dalian, China. Renewable Energy 2007;32:2603-16. doi: $10.1016 / j$.renene.2006.12.015.

[17] Lund R., Østergaard DS, Yang X, Mathiesen BV. Comparison of Low-temperature District Heating Concepts in a Long-Term Energy System Perspective. Internaltional Journal of Sustainable Energy Planning and Management 2017;12:5-18.

[18] Flores JFC, Lacarrière B, Chiu JNW, Martin V, Castro JF. Assessing the techno-economic impact of low-temperature subnets in conventional district heating networks. Energy Procedia 2017;116:260-72. doi:10.1016/j.egypro.2017.05.073.

[19] Cuadrado RS. Return temperature influence of a district heating network on the CHP plant production costs. 2009.

[20] Kontu K, Rinne S, Olkkonen V, Lahdelma R, Salminen P. Multicriteria evaluation of heating choices for a new sustainable residential area. Energy \& Buildings 2015;93:169-79. doi: 10.1016/j.enbuild.2015.02.003.

[21] Mahapatra K. Energy use and $\mathrm{CO} 2$ emission of new residential buildings built under specific requirements - The case of Växjö municipality , Sweden. Applied Energy 2015;152:31-8. doi:10.1016/j.apenergy.2015.04.089.

[22] Ristimäki M, Säynäjoki A, Heinonen J, Junnila S. Combining life cycle costing and life cycle assessment for an analysis of a new residential district energy system design. Energy 2013;63:168-79. doi:10.1016/j.energy.2013.10.030. 
[23] Granryd E, Ekroth I, Lundqvist P, Melinder $\AA$, Palm B, Rohlin P. REFRIGERATING ENGINEERING. 2011.

[24] F-Chart Software. Engineering Equation Solver n.d.

[25] Estonian Weather Service. Seawater temperature 2018.

[26] Danish Meteorological Institute (DMI). Modelled hydrographic conditions across Øresund/Kongedybet. 2017.

[27] Wallentén P. Steady-state heat loss from insulated pipes. Byggnadsfysik LTH, Lunds Tekniska Högskola General; 1991.

[28] Latõšov E, Volkova A, Siirde A, Kurnitski J, Thalfeldt M. Primary energy factor for district heating networks in European Union member states. Energy Procedia 2017;116:69-77. doi:10.1016/j.egypro.2017.05.056.

[29] Method for determining the amount of carbon dioxide discharged into the atmosphere. Regulation of the Minister of the Environment, State Gazette 27.12.2016 nr 86 (in Estonian) https://www.riigiteataja.ee/akt/129122016063. n.d.

[30] Loo L, Maaten B, Konist A, Siirde A, Neshumayev D, Pihu T. Carbon dioxide emission factors for oxy-fuel CFBC and aqueous carbonation of the Ca-rich oil shale ash. Energy Procedia 2017;128:144-9. doi:10.1016/j.egypro.2017.09.034.

[31] Konist A, Maaten B, Loo L, Neshumayev D, Pihu T. Mineral Sequestration of CO2 by Carboation of Ca-Rich Oil Shale Ash in Natural Conditions. Oil Shale 2016;33:248-59. doi:10.3176/oil.2016.3.04.

[32] Pieper H, Ommen T, Buhler F, Lava Paaske B, Elmegaard B, Brix Markussen W. Allocation of investment costs for large-scale heat pumps supplying district heating. Energy Procedia 2018;147:358-67. doi:10.1016/j.egypro.2018.07.104.

[33] Ashfaq A, Ianakiev A. Cost-minimised design of a highly renewable heating network for fossil-free future. Energy 2018;152:613-26. doi:10.1016/j.energy.2018.03.155.

[34] Estonian Gas Association. n.d.

[35] Danish Energy Agency. Technology Data for Energy Plants Updated chapters, August 2016 2016:183. doi:ISBN: 978-87-7844-857-6.

[36] Nord Pool 2017. Historical Market Data n.d.

[37] European Comission. EU Reference Scenario 2016, Energy, Transport and GHG emissions, Trends to 2050. 2016. doi:10.2833/9127.

\section{Appendix A HP design model}

The HP design model overview is shown in a Q-T diagram and a log(p)-h diagram in Figure A. 1. As depicted, the pinch point temperature of $5 \mathrm{~K}$ was kept and all the heat was used to heat the $\mathrm{DH}$ water. The discharge temperature after the compressor was $140{ }^{\circ} \mathrm{C}$. All state points are shown in the $\log (\mathrm{p})$-h diagram for the two-stage HP. 

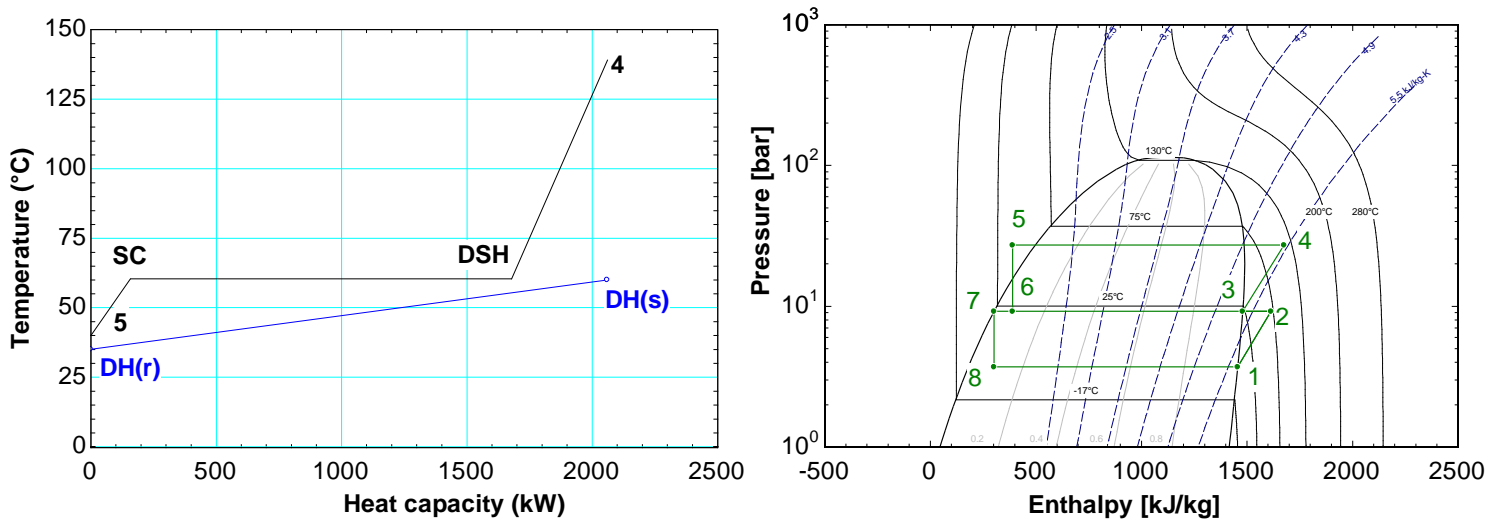

Figure A. 1: Q-T diagram (left) and $\log (\mathrm{p})$-h diagram (right) for the HP design model 